\title{
APPLICATION OF CT-PRO ALGORITHM FOR CRIME ANALYSIS
}

\author{
Eduardus Hardika Sandy Atmaja ${ }^{1)}$, Risky Simaremare ${ }^{2)}$, \\ Paulina Heruningsih Prima Rosa ${ }^{3)}$
}

Program Studi Informatika, Fakultas Sains dan Teknologi, Universitas Sanata Dharma Jl. Paingan, Maguwoharjo, Depok, Krodan, Maguwoharjo, Kec. Depok, Kabupaten Sleman,

Daerah Istimewa Yogyakarta

Email : ${ }^{1}$ edo@usd.ac.id

\begin{abstract}
The large amount of crime data generally becomes a pile of data that lacks of information. Data mining can be implemented in many areas, crime is one of them. Data mining can be used to find information from crime data that has been collected by the police. This study analyzed 3.198 crime data of Polresta Yogyakarta in 2016-2018. This study was aimed to determine the pattern of interrelationships between regions with its potential crime using association rule mining with CT-PRO algorithm. System testing was done by changing support and confidence values to find best crime patterns. The results were support and confidence values that can produce association rules are $8,59 \%$ and $70 \%$ with one rule, namely: "If the committed crime is CURAT then the crime occures in MUKIM." The rule has 70,5\% confidence, 275 support count and 1,66 lift ratio which means the rule were in the strong category.
\end{abstract}

Keywords: Data Mining, Association, CT-PRO, Crime

\section{Pendahuluan}

Tindak kejahatan adalah tindakan yang menentang aturan hukum serta adanya sanksi pidana yang dapat dikenakan bagi siapa saja yang melakukan pelanggaran tersebut[1]. Kejahatan adalah aktivitas yang bertujuan untuk melakukan sesuatu tindakan jahat dan merugikan orang lain yang dilakukan oleh pribadi atau kelompok[2]. Ada banyak contoh tindak kejahatan yang dilakukan di lingkungan masyarakat misalnya pencurian, pembunuhan, penipuan, pengedaran obat-obat terlarang, dan lain sebagainya. Tindak kejahatan juga dipengaruhi oleh banyak faktor yang beragam dan kompleks misalnya lingkungan pergaulan, tingkat pendidikan, daya emosional, dan lain-lain.

Menurut Badan Pusat Statistik (BPS), telah terjadi kecenderungan peningkatan kasus kejahatan atau kriminalitas di Indonesia pada tahun 2015-2017. Sebanyak 352.936 kasus kejahatan telah terjadi selama tahun 2015 dan meningkat pada tahun 2016 menjadi 357.197. Tetapi terjadi penurunan pada tahun 2017 yaitu menjadi 336.652 kasus. Data tersebut merupakan data yang berasal dari Polri. Secara lebih spesifik BPS juga menyediakan data yang berasal dari Polda Daerah Istimewa Yogyakarta (DIY), yaitu terdapat 7.251 kasus kejahatan yang terjadi selama tahun 2017[3]. Kasus-kasus kejahatan tersebut semakin lama semakin meresahkan masyarakat dan mengharuskan pihak kepolisian untuk terus menyelidikinya.

Banyaknya data tindak kejahatan sering kali hanya menjadi tumpukan data yang miskin akan informasi. Untuk menyelesaikan permasalahan tersebut maka perlu suatu teknik tertentu yang dapat digunakan untuk mengelola dan menganalisis tumpukan data. Teknik yang dapat digunakan untuk menggali nilai dari tumpukan data tersebut adalah data mining.

Data mining merupakan bagian dari Knowledge Discovery in Database (KDD) yaitu sebuah aktivitas analisis data dalam jumlah besar untuk mencari pola atau keterkaitan data[4]. 
Data mining dapat digunakan untuk menggali informasi dari data tindak kejahatan yang telah dikumpulkan oleh pihak kepolisian. Informasi yang dapat diperoleh berupa jenis tindak kejahatan yang terjadi di wilayah-wilayah tertentu. Informasi tersebut dapat diperoleh dengan metode association rule mining yang ada dalam teknik data mining.

Terdapat beberapa penelitian yang telah mengimplementasikan data mining pada data tindak kejahatan[5][6]. Kedua penelitian tersebut menggunakan metode association rule mining dan algoritma apriori untuk menganalisis data kejahatan. Hasilnya berupa pola-pola kejahatan yang terjadi dan saling berkaitan satu sama lain. Hasil tersebut dapat dimanfaatkan sebagai bahan pertimbangan kepolisian dalam usaha mencegah kriminalitas.

Kelemahan dari algoritma apriori adalah waktu eksekusi yang cenderung lama karena terdapat mekanisme brute force dalam mengkombinasikan itemset. Kelemahan tersebut dapat di atasi dengan memanfaatkan algoritma fp-growth yang berbasis tree. Penelitian tersebut juga telah dilakukan untuk menemukan pola peminjaman buku di perpustakaan[7]. Hasilnya berupa pola kombinasi buku yang saling berkaitan. Hasil tersebut dapat dimanfaatkan oleh peminjam buku untuk melihat rekomendasi buku lain yang dapat dipinjam ketika sebuah buku akan dipinjam.

Terdapat juga penelitian lain yang telah mengimplementasikan association rule mining dengan menggunakan algoritma ct-pro untuk menemukan pola tindak kejahatan perdagangan manusia[8]. Kelemahan dari algoritma fp-growth diperbaiki oleh algoritma $c t$ pro yaitu dengan mengganti penggunaan $f p$-tree dengan membuat compressed fp-tree pada langkah pembangunan global tree. Salah satu kelemahan $f p$-tree adalah overhead dalam membangun banyak conditional fp-tree dalam tahap mining yang mengurangi performa algoritma ketika pola bertambah panjang dan atau minimal support bertambah kecil sehingga membutuhkan waktu yang lebih panjang dan memori yang cukup besar. Hasil dari penelitian tersebut berupa pola tindak kejahatan perdagangan manusia yang sesuai dengan kondisi di lapangan. Hasil tersebut tentu saja dapat membantu pihak kepolisian dalam mencegah terjadikan tindak kejahatan perdagangan manusia.

Berdasarkan permasalahan dan beberapa fakta di atas maka penelitian ini mencoba menganalisis data tindak kejahatan di Yogyakarta dengan mengimplementasikan association rule mining dan algoritma Compact Tree-Apriori (CT-PRO). Dengan adanya penelitian ini, diharapkan dapat membantu polisi dalam mengupayakan usaha-usaha pencegahan tindak kejahatan yang semakin marak terjadi di masyarakat. Dengan informasi tersebut, masyarakat juga dapat ikut berhati-hati terhadap kemungkinan terjadinya kejahatan di tempat-tempat tertentu.

\section{Metodologi Penelitian}

Penelitian ini melalui serangkaian tahap-tahap untuk mengimplementasikan algoritma CT-PRO dalam menemukan pola kejahatan. Gambar 1 menunjukkan tahap-tahap yang dilakukan dalam penelitian ini.

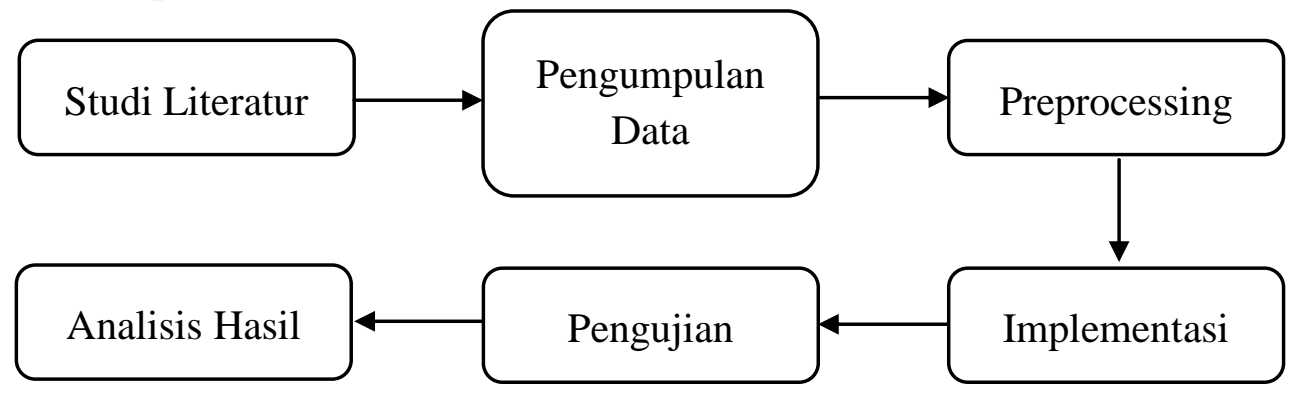

Gambar 1. Metodologi Penelitian 
Gambar 1 memperlihatkan bagan metodologi penelitian yang dilakukan pada penelitian ini. Tahap pertama adalah studi literatur, pada tahap ini dilakukan studi mengenai teori dan penelitian sebelumnya yang berkaitan dengan penelitian ini. Literatur yang digunakan berasal dari buku, jurnal, dan publikasi ilmiah lainnya. Tahap kedua adalah pengumpulan data, pada tahap ini dilakukan metode dokumentasi yaitu mempelajari dan melihat dokumen-dokumen yang telah tersedia sebelumnya. Caranya adalah dengan menelusuri dan mencatat informasi yang dibutuhkan kaitannya dengan data laporan kepolisian. Data yang diperoleh adalah data kasus kejahatan yang didapatkan dari laporan tindak kejahatan yang ada di Polresta Yogyakarta dari tahun 2016-2018. Data yang diambil meliputi atribut tindak kejahatan, kecamatan, TKP, dan tahun kejadian. Pada tahap ketiga, data laporan polisi yang telah diperoleh diolah agar siap untuk diproses. Beberapa hal yang dilakukan adalah seleksi data, pembersihan data, dan transformasi data.

Tahap keempat adalah implementasi, implementasi algoritma CT-PRO dilakukan pada tahap ini ke dalam bahasa pemrograman Java. Adapun algoritma CT-PRO ditunjukkan dalam diagram flowchart pada Gambar 2 di bawah ini.
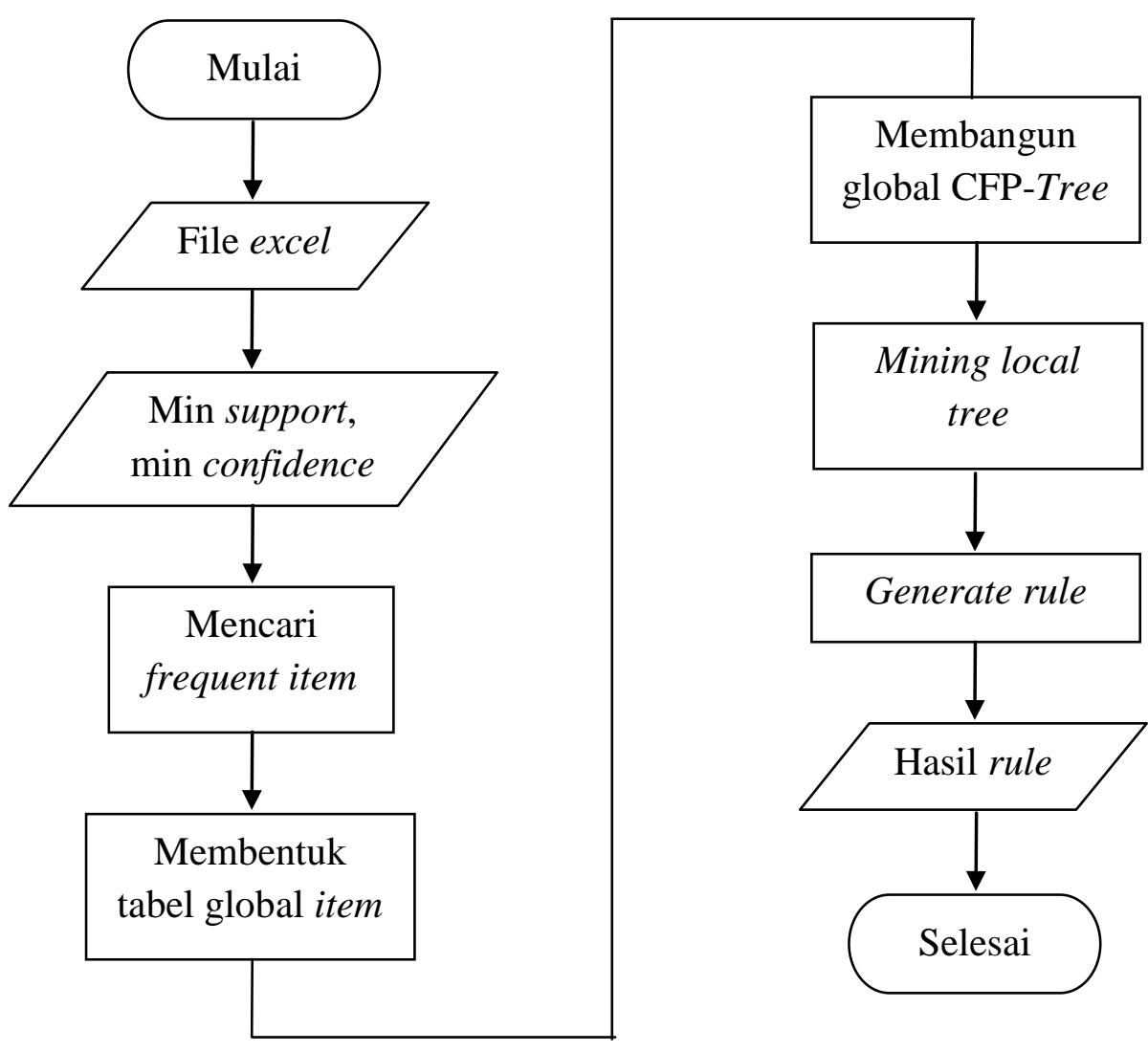

Gambar 2. Flowchart CT-PRO

Tahap kelima adalah pengujian terhadap implementasi CT-PRO dengan cara mengubah-ubah nilai min support dan min confidence untuk menemukan aturan yang terbaik. Aturan terbaik yang dimaksud adalah aturan dengan nilai support dan confidence yang tertinggi. Hasil dari tahap pengujian selanjutnya dilakukan analisis pada tahap keenam. Pada tahap ini dilakukan penarikan kesimpulan terhadap temuan yang didapatkan dan memberikan saran guna perbaikan dari kelemahan yang ditemukan. 


\section{Hasil dan Pembahasan}

\subsection{Sampel data}

Sampel data yang digunakan sebanyak 10 data dari total 3.198 data tindak kejahatan di Polresta Yogyakarta untuk memberikan gambaran proses algoritma CT-PRO. Data tersebut sudah melalui tahap preprocessing dan siap untuk diolah. 10 data tersebut ditunjukkan pada Tabel 1 di bawah ini.

Tabel 1. Sampel data tindak kejahatan

\begin{tabular}{|c|l|l|l|l|}
\hline No & Jenis Tindak Kejahatan & \multicolumn{1}{|c|}{ Kecamatan } & \multicolumn{1}{|c|}{ TKP } & Tahun \\
\hline 1 & Penipuan & Gondomanan & ATM & 2016 \\
\hline 2 & Penggelapan & Mantrijeron & Perusahaan & 2016 \\
\hline 3 & Pemalsuan Dokumen & Mergangsan & Perusahaan & 2016 \\
\hline 4 & Pencurian & Gondomanan & Toko & 2016 \\
\hline 5 & Penipuan & Gondomanan & ATM & 2017 \\
\hline 6 & Penipuan & Umbulharjo & ATM & 2017 \\
\hline 7 & Penggelapan & Tegalrejo & Perusahaan & 2017 \\
\hline 8 & Penggelapan & Umbulharjo & Perusahaan & 2018 \\
\hline 9 & Pencurian & Gondomanan & Pasar & 2018 \\
\hline 10 & Penipuan & Gondokusuman & ATM & 2018 \\
\hline
\end{tabular}

\subsection{Pencarian frequent item}

Pada langkah ini dilakukan proses pencarian item yang kemunculannya tidak kurang dari threshold yang ditentukan yaitu min support count 2 (20\%). Mula-mula semua item dari Tabel 1 diambil dengan menghilangkan item ganda. Item yang dimaksud adalah isi dari kolom jenis tindak kejahatan, kecamatan dan TKP. Selanjutnya dihitung jumlah kemunculan masing-masing item pada Tabel 1. Daftar dari item-item tersebut ditunjukkan pada Tabel $2 \mathrm{a}$. Selanjutnya dilakukan penghapusan terhadap item-item pada Tabel 2a yang tidak memenuhi threshold. Item-item tersebut selanjutnya diurutkan berdasarkan count terbanyak dan diberi id global seperti yang terlihat pada Tabel $2 \mathrm{~b}$.

Tabel 2. Daftar global item

\begin{tabular}{|c|l|c|}
\hline No & \multicolumn{1}{|c|}{ Item } & Count \\
\hline 1 & Penipuan & 4 \\
\hline 2 & Penggelapan & 3 \\
\hline 3 & Pemalsuan Dokumen & 1 \\
\hline 4 & Pencurian & 2 \\
\hline 5 & Gondomanan & 4 \\
\hline 6 & Mantrijeron & 1 \\
\hline 7 & Mergangsan & 1 \\
\hline 8 & Umbulharjo & 2 \\
\hline 9 & Tegalrejo & 1 \\
\hline 10 & Gondokusuman & 1 \\
\hline 11 & ATM & 4 \\
\hline 12 & Perusahaan & 4 \\
\hline 13 & Toko & 1 \\
\hline 14 & Pasar & 1 \\
\hline
\end{tabular}

\begin{tabular}{|c|l|c|}
\hline ID Global & \multicolumn{1}{|c|}{ Item } & Count \\
\hline 1 & Penipuan & 4 \\
\hline 2 & Gondomanan & 4 \\
\hline 3 & ATM & 4 \\
\hline 4 & Perusahaan & 4 \\
\hline 5 & Penggelapan & 3 \\
\hline 6 & Pencurian & 2 \\
\hline 7 & Umbulharjo & 2 \\
\hline
\end{tabular}

(b)

(a) 
Setelah diperoleh tabel global item, selanjutnya adalah melakukan konversi data pada Tabel 1 sesuai dengan id global pada Tabel $2 \mathrm{~b}$ menjadi Tabel 3a. Hasil konversi data pada Tabel 3a diurutkan secara ascending sesuai dengan urutan id global yang ditunjukkan pada Tabel 3b.

Tabel 3. Konversi itemset

\begin{tabular}{|c|l|}
\hline No & \multicolumn{1}{|c|}{ Item } \\
\hline 1 & $1,2,3$ \\
\hline 2 & 5,4 \\
\hline 3 & 4 \\
\hline 4 & 6,2 \\
\hline 5 & $1,2,3$ \\
\hline 6 & $1,7,3$ \\
\hline 7 & 5,4 \\
\hline 8 & $5,7,4$ \\
\hline 9 & 6,2 \\
\hline 10 & 1,3 \\
\hline
\end{tabular}

(a)

\begin{tabular}{|c|l|}
\hline No & \multicolumn{1}{|c|}{ Item } \\
\hline 1 & $1,2,3$ \\
\hline 2 & 4,5 \\
\hline 3 & 4 \\
\hline 4 & 2,6 \\
\hline 5 & $1,2,3$ \\
\hline 6 & $1,3,7$ \\
\hline 7 & 4,5 \\
\hline 8 & $4,5,7$ \\
\hline 9 & 2,6 \\
\hline 10 & 1,3 \\
\hline
\end{tabular}

(b)

\subsection{Pembangunan global CFP-Tree}

Proses pembangunan global CFP-Tree membutuhkan tabel global item dan tabel konversi itemset. Adapun algoritma pembentukan global CFP-Tree adalah sebagai berikut :

a. Inisialisasi tree, buat node baru untuk setiap item yang ada pada tabel global item (Tabel 2b) dan diatur sebagai anak kiri dari setiap node yang terbentuk.

b. Mengakses setiap item yang ada pada itemset (Tabel 3b).

c. Jika item yang ada pada itemset adalah currentNode maka count yang ada pada currentNode ditambah satu.

d. Jika item tersebut tidak sama dengan currentNode maka lakukan penelusuran untuk anak dari currentNode.

e. Jika item tersebut ada pada anak dari currentNode maka count yang ada pada anak currentNode ditambah satu. Jika tidak buat cabang baru untuk item baru dan count pada cabang baru tersebut ditambah satu.

f. Ulangi langkah b sampai e untuk setiap itemset hingga seluruh itemset sudah diproses.

Hasil dari proses pembangunan global CFP-Tree dapat dilihat pada Gambar 3.

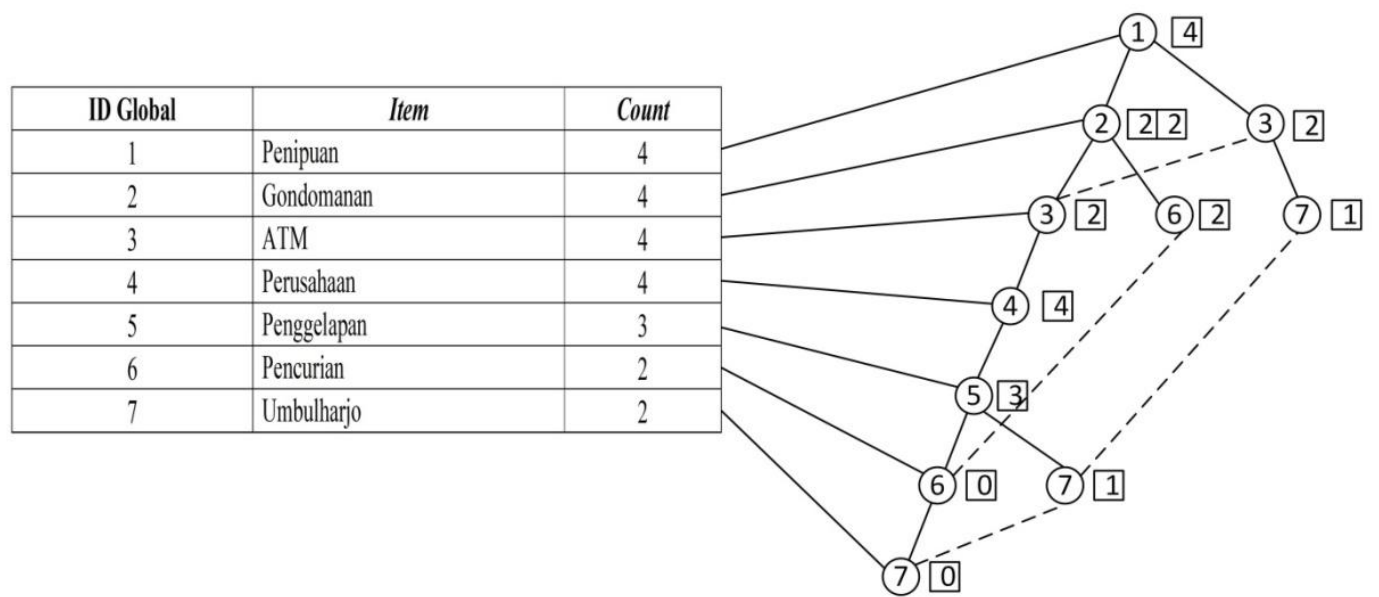

Gambar 3. Global CFP-Tree 


\subsection{Mining local tree}

Konsep dari algoritma CT-PRO adalah bottom-up mining sehingga tabel global item diurutkan mulai dari item yang memiliki frekuensi terkecil hingga terbesar. Proses mining dilakukan satu persatu dimulai dari global item terkecil untuk menjadi local tree. Pada pembuatan local item table, dilakukan seleksi berdasarkan nilai threshold yang telah ditentukan.

Sebagai contoh akan dibangun local CFP-Tree node 3 dengan cara bottom-up. Berdasarkan global CFP-Tree terdapat dua item yang menjadi parent dari node 3 yaitu item 1 dan 2. Kedua item tersebut di hitung jumlah kemunculannya yang mengandung node 3 seperti yang di perlihatkan pada Tabel 4.

Tabel 4. Proses mendapatkan local item table

\begin{tabular}{|c|c|}
\hline ID Global & Count \\
\hline 1 & 4 \\
\hline 2 & 2 \\
\hline
\end{tabular}

(a)

$\longrightarrow$\begin{tabular}{|c|c|c|}
\hline ID Lokal & Item & Count \\
\hline 1 & Penipuan & 4 \\
\hline 2 & Gondomanan & 2 \\
\hline
\end{tabular}

(b)

Seluruh item yang terdapat pada Tabel 4a diseleksi berdasarkan threshold yaitu 2 (20\%). Lalu item yang telah diseleksi akan digunakan untuk membuat local item table pada Tabel 4b. Langkah selanjutnya adalah membangun local CFP-Tree dari local item table yang telah terbentuk. Gambar 4 menunjukkan jumlah item yang mengandung item 1 (Penipuan) adalah 4. Sedangkan jumlah item yang mengandung itemset 1 dan 2 (Penipuan dan Gondomanan) adalah 2.

\begin{tabular}{|c|c|c|}
\hline ID Lokal & Item & Count \\
\hline 1 & Penipuan & 4 \\
\hline 2 & Gondomanan & 2 \\
\hline
\end{tabular}

Gambar 4. Local CFP-Tree node 3

Langkah selanjutnya adalah membuat frequent itemset berdasarkan node 3 untuk dijadikan root yang diikuti dengan node-node lain dari local CFP-Tree sebagai subtree. Sebagai contoh, node 3 memiliki subtree node 2 dan node 1 sesuai dengan node yang ada pada local CFP-Tree. Proses membangun frequent itemset untuk node 3 ditunjukkan pada Gambar 5.

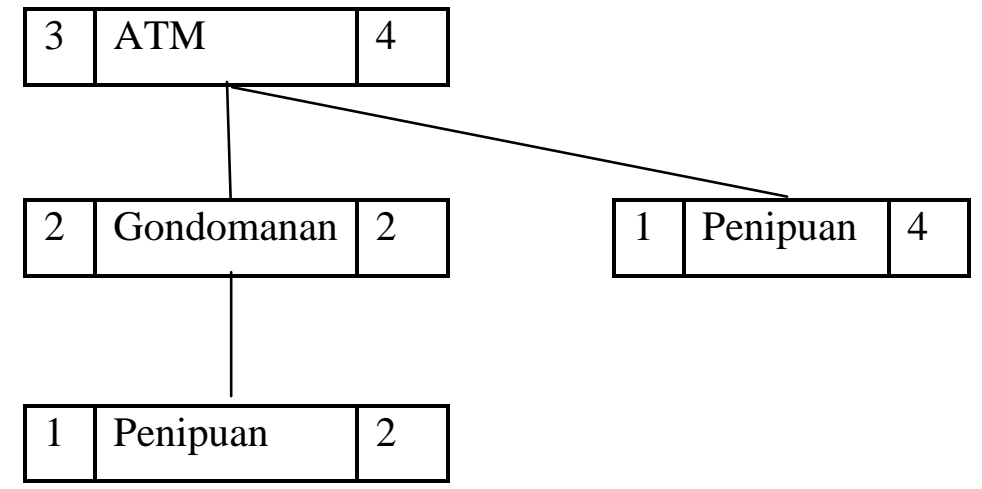

Gambar 5. Proses mendapatkan frequent itemset

Selanjutnya dilakukan transformasi ke dalam bentuk tabel berdasarkan Gambar 5 menjadi frequent itemset yang ditunjukkan pada Tabel 5. 
Tabel 5. Frequent itemset

\begin{tabular}{|c|l|c|}
\hline No & \multicolumn{1}{|c|}{ Itemset } & Count \\
\hline 1 & ATM, Gondomanan, Penipuan & 2 \\
\hline 2 & ATM, Gondomanan & 2 \\
\hline 3 & ATM, Penipuan & 4 \\
\hline
\end{tabular}

\subsection{Generate rule}

Setelah frequent itemset untuk node 3 ditemukan, langkah selanjutnya adalah membentuk aturan yang diperoleh dari proses subset frequent itemset berdasarkan Tabel 5. Dari hasil subset tersebut dilakukan perhitungan nilai support, confidence, dan lift ratio seperti yang diperlihatkan pada Tabel 6 .

Tabel 6. Frequent itemset dengan nilai support dan confidence

\begin{tabular}{|c|c|c|c|c|c|}
\hline No & A & B & $\begin{array}{r}\text { Support } \\
\text { Count (A) }\end{array}$ & $\begin{array}{c}\text { Support Count } \\
\text { (A U B) }\end{array}$ & Confidence \\
\hline 1 & $\begin{array}{c}\text { ATM, } \\
\text { Gondomanan }\end{array}$ & Penipuan & 2 & 2 & $2 / 2=1$ \\
\hline 2 & ATM, Penipuan & Gondomanan & 4 & 2 & $2 / 4=0,5$ \\
\hline 3 & Gondomanan, & ATM & 2 & 2 & $2 / 2=1$ \\
\hline 4 & Penipuan & Gondomanan, & 4 & 2 & $2 / 4=0,5$ \\
\hline 5 & ATM & Gondomanan & 4 & 2 & $2 / 4=0,5$ \\
\hline 6 & ATM & Penipuan & 4 & 4 & $4 / 4=1$ \\
\hline 7 & Gondomanan & ATM, Penipuan & 4 & 2 & $2 / 4=0,5$ \\
\hline 8 & Gondomanan & ATM & 4 & 2 & $2 / 4=0,5$ \\
\hline 9 & Gondomanan & Penipuan & 4 & 2 & $2 / 4=0,5$ \\
\hline 10 & Penipuan & ATM, Gondomanan & 4 & 2 & $2 / 4=0,5$ \\
\hline 11 & Penipuan & ATM & 4 & 4 & $4 / 4=1$ \\
\hline 12 & Penipuan & Gondomanan & 4 & 2 & $2 / 4=0,5$ \\
\hline & Beberapan & & & \\
\hline
\end{tabular}

Beberapa rumus yang digunakan adalah sebagai berikut [9]:

$$
\begin{gathered}
\operatorname{support}(A=>B)=\frac{\text { Jumlah transaksi mengandung } A \text { dan } B}{\text { Total transaksi }} \\
\operatorname{confidence}(A=>B)=\frac{\text { Jumlah transaksi mengandung } A \text { dan } B}{\text { Jumlah transaksi mengandung } A}
\end{gathered}
$$


Setelah ditemukan nilai support dan confidence maka dilakukan penyeleksian aturan yang memenuhi nilai minimum confidence sebesar 1 . Lalu sekaligus dihitung nilai lift ratio dari aturan yang telah lolos minimum confidence. Untuk menghitung lift ratio dilakukan dengan membagi nilai dari confidence dengan benchmark confidence[9]. Nilai benchmark confidence sendiri, dihitung dengan membagi banyaknya kemunculan consequent yang dibagi dengan banyaknya data tindak kejahatan[9]. Tabel 7 menunjukkan aturan-aturan yang memenuhi nilai minimum confidence beserta nilai lift ratio.

Tabel 7. Aturan yang memenuhi minimum confidence beserta lift ratio

\begin{tabular}{|c|l|l|c|c|c|}
\hline No & \multicolumn{1}{|c|}{ A } & B & Confidence & $\begin{array}{c}\text { Benchmark } \\
\text { Confidence }\end{array}$ & $\begin{array}{c}\text { Lift } \\
\text { Ratio }\end{array}$ \\
\hline 1 & ATM, Gondomanan & Penipuan & 1 & 0,4 & 2,5 \\
\hline 2 & Gondomanan, Penipuan & ATM & 1 & 0,4 & 2,5 \\
\hline 3 & ATM & Penipuan & 1 & 0,4 & 2,5 \\
\hline 4 & Penipuan & ATM & 1 & 0,4 & 2,5 \\
\hline
\end{tabular}

Dari hasil yang diperoleh pada Tabel 7 nilai lift ratio yang dihasilkan untuk semua rule yang berhasil dibentuk memiliki nilai lebih besar dari 1 (lift ratio > 1). Hal ini menunjukkan bahwa semua rule yang didapatkan bersifat kuat.

\subsection{Pengujian dengan seluruh data}

Pengujian dilakukan pada seluruh data tindak kejahatan yang terjadi di Polresta Yogyakarta pada tahun 2016-2018 menggunakan nilai min support dan confidence yang berbeda-beda. Jika nilai support count dan min confidence menghasilkan jumlah aturan yang sama secara berturut-turut maka akan diambil nilai support count dan min confidence yang terbesar untuk ditampilkan di Tabel 8 . Tabel 8 berisi jumlah aturan yang diperoleh pada setiap variasi nilai min support dan min confidence.

Tabel 8. Hasil pengujian seluruh data

\begin{tabular}{|c|c|c|c|c|c|c|c|}
\hline \multirow{2}{*}{$\begin{array}{c}\text { Support } \\
\text { Count }\end{array}$} & \multirow{2}{*}{$\begin{array}{c}\text { Minimum } \\
\text { Support }\end{array}$} & \multicolumn{7}{|c|}{ Minimum Confidence } \\
\cline { 3 - 8 } & & $\mathbf{5 0 \%}$ & $\mathbf{6 0 \%}$ & $\mathbf{7 0 \%}$ & $\mathbf{8 0 \%}$ & $\mathbf{9 0 \%}$ & $\mathbf{1 0 0 \%}$ \\
\hline 1 & $0,03 \%$ & 908 & 713 & 586 & 548 & 531 & 531 \\
\hline 2 & $0,06 \%$ & 511 & 390 & 263 & 225 & 208 & 208 \\
\hline 3 & $0,09 \%$ & 223 & 164 & 107 & 72 & 55 & 55 \\
\hline 4 & $0,12 \%$ & 141 & 97 & 63 & 43 & 26 & 26 \\
\hline 5 & $0,15 \%$ & 103 & 68 & 45 & 25 & 16 & 16 \\
\hline 6 & $0,18 \%$ & 85 & 53 & 33 & 16 & 10 & 10 \\
\hline 7 & $0,21 \%$ & 71 & 42 & 26 & 11 & 6 & 6 \\
\hline 8 & $0,25 \%$ & 60 & 35 & 21 & 9 & 4 & 4 \\
\hline 9 & $0,28 \%$ & 54 & 31 & 18 & 6 & 3 & 3 \\
\hline 10 & $0,31 \%$ & 48 & 27 & 15 & 3 & 2 & 2 \\
\hline 11 & $0,34 \%$ & 44 & 24 & 14 & 3 & 2 & 2 \\
\hline 13 & $0,40 \%$ & 35 & 19 & 12 & 3 & 2 & 2 \\
\hline 14 & $0,43 \%$ & 30 & 17 & 10 & 3 & 2 & 2 \\
\hline 15 & $0,46 \%$ & 28 & 17 & 10 & 3 & 2 & 2 \\
\hline 16 & $0,50 \%$ & 25 & 14 & 9 & 2 & 1 & 1 \\
\hline 18 & $0,56 \%$ & 22 & 13 & 9 & 2 & 1 & 1 \\
\hline
\end{tabular}


Tabel 9. Hasil pengujian seluruh data (lanjutan)

\begin{tabular}{|c|c|c|c|c|c|c|c|}
\hline \multirow{2}{*}{$\begin{array}{c}\text { Support } \\
\text { Count }\end{array}$} & \multirow{2}{*}{$\begin{array}{c}\text { Minimum } \\
\text { Support }\end{array}$} & \multicolumn{7}{|c|}{ Minimum Confidence } \\
\cline { 3 - 8 } & & $\mathbf{5 0 \%}$ & $\mathbf{6 0 \%}$ & $\mathbf{7 0 \%}$ & $\mathbf{8 0 \%}$ & $\mathbf{9 0 \%}$ & $\mathbf{1 0 0 \%}$ \\
\hline 18 & $0,56 \%$ & 22 & 13 & 9 & 2 & 1 & 1 \\
\hline 19 & $0,59 \%$ & 19 & 10 & 8 & 2 & 1 & 1 \\
\hline 21 & $0,65 \%$ & 17 & 10 & 8 & 2 & 1 & 1 \\
\hline 28 & $0,87 \%$ & 13 & 7 & 5 & 1 & 0 & 0 \\
\hline 29 & $0,90 \%$ & 12 & 7 & 5 & 1 & 0 & 0 \\
\hline 32 & $1,00 \%$ & 9 & 6 & 4 & 1 & 0 & 0 \\
\hline 47 & $1,47 \%$ & 8 & 5 & 3 & 1 & 0 & 0 \\
\hline 49 & $1,53 \%$ & 7 & 4 & 3 & 1 & 0 & 0 \\
\hline 50 & $1,56 \%$ & 6 & 4 & 3 & 1 & 0 & 0 \\
\hline 66 & $2,06 \%$ & 5 & 4 & 3 & 1 & 0 & 0 \\
\hline 79 & $2,47 \%$ & 3 & 2 & 2 & 1 & 0 & 0 \\
\hline 80 & $2,50 \%$ & 2 & 2 & 2 & 1 & 0 & 0 \\
\hline 275 & $8,59 \%$ & 1 & 1 & 1 & 0 & 0 & 0 \\
\hline 276 & $8,63 \%$ & 0 & 0 & 0 & 0 & 0 & 0 \\
\hline
\end{tabular}

Dari hasil pengujian perbandingan jumlah aturan asosiasi pada 3.198 laporan tindak kejahatan dari tahun 2016-2018 diperoleh informasi bahwa nilai min support 8,59\% dengan nilai confidence $70 \%$ menghasilkan aturan asosiasi yang baik karena aturan tersebut memenuhi nilai min support dan min confidence tertinggi, yang berarti bahwa aturan tersebut merupakan aturan yang paling sering muncul dengan tingkat kepercayaan tertinggi.

Aturan yang dihasilkan yaitu:

"Jika tindak kejahatan yang dilakukan adalah CURAT maka tindak kejahatan terjadi di MUKIM"

Tingkat Kepercayaan : 70.5\%

Support Count : 275

Lift Rasio : 1.66 ( Aturan Kuat )

Selain itu, diperoleh informasi bahwa nilai min support 8,63\% dengan nilai confidence dari 50\% hingga 100\% tidak menghasilkan aturan asosiasi maka proses uji coba berhenti.

\subsection{Konfirmasi hasil aturan asosiasi}

Hasil aturan asosiasi yang telah diperoleh dari penelitian ini, selanjutnya dilakukan konfirmasi kepada pihak Polresta Yogyakarta selaku pemilik data. Berdasarkan konfirmasi dari Ibu Gita selaku BAMIN Satreskrimum Polresta Yogyakarta, dapat diperoleh informasi bahwa aturan asosiasi tindak kejahatan terkuat yaitu "Jika tindak kejahatan yang dilakukan adalah CURAT maka tindak kejahatan terjadi di MUKIM" telah sesuai dengan keadaan di lapangan. Ibu Gita menambahkan bahwa motif CURAT (pencurian dengan pemberatan) banyak dilakukan dengan cara perusakan rumah yang penghuninya sedang tidak ada. Konfirmasi juga dilakukan untuk beberapa hasil pengujian yang lain. Dari hasil konfirmasi tersebut dapat diperoleh kesimpulan bahwa hasil aturan asosiasi yang diperoleh oleh sistem sudah sesuai dengan keadaan di lapangan. 


\section{Kesimpulan}

Kesimpulan yang diperoleh dari penelitian ini yaitu:

a. Algoritma CT-PRO dapat diterapkan untuk menganalisis tindak kejahatan yang terjadi di Polresta Yogyakarta dengan menemukan aturan asosiasi antar item.

b. Dengan menggunakan data tindak kejahatan di Polresta Yogyakarta pada tahun 20162018, batas tertinggi minimum support dan confidence yang dapat menghasilkan aturan asosiasi adalah $8,59 \%$ dan $70 \%$ dengan hasil satu aturan yaitu: "Jika tindak kejahatan yang dilakukan adalah CURAT maka tindak kejahatan terjadi di MUKIM.” Aturan tersebut memiliki tingkat kepercayaan sebesar $70.5 \%$, support count sebesar 275 dan memiliki lift ratio senilai 1.66 yang berarti aturan termasuk kategori kuat.

c. Aturan asosiasi yang dihasilkan sudah sesuai dengan kondisi di lapangan.

Saran yang dapat disampaikan berdasarkan temuan yang diperoleh dari penelitian ini yaitu:

a. Penelitian selanjutnya hendaknya dapat melakukan komparasi terhadap algoritma association rule lainnya.

b. Penambahan atribut juga perlu dilakukan untuk mendapatkan hasil aturan yang lebih baik.

\section{Ucapan Terimakasih}

Penulis mengucapkan terima kasih kepada Polresta Yogyakarta yang telah menyediakan data tindak kejahatan yang digunakan dalam penelitian ini.

\section{Daftar Pustaka}

[1] Moeljatno. (1993). Asas Asas Hukum Pidana. Rineka Cipta. Hal. 54.

[2] Nagib, C. (2014). Studi Deskriptif Faktor-faktor yang Menyebabkan Terjadinya Tindak Kriminal oleh Anak-anak Di Balai Pemasyarakatan Purwokerto. Skripsi Fakultas Psikologi Universitas Muhammadiyah Purwokerto.

[3] Badan Pusat Statistik. (2018). Statistik Kriminal 2018. Badan Pusat Statistik.

[4] Han, J., Kamber, M., \& Pei, J. (2012). Data Mining: Concepts and Techniques 3rd Edition. Morgan Kaufmann.

[5] Atmaja, E. H. S. (2017). Analisis Pola Tindak Kejahatan Menggunakan Visualisasi Aturan Asosiasi Berbasis Graph. Jurnal Media Teknika, 12(1), 1-66.

[6] Fadlina. (2014). Data Mining Untuk Analisa Tingkat Kejahatan Jalanan dengan Algoritma Association Rule Metode Apriori. Jurnal Informasi Dan Teknologi Ilmiah (INTI), III(1), 144-154.

[7] Kadafi, M. (2018). Penerapan Algoritma FP-GROWTH untuk Menemukan Pola Peminjaman Buku Perpustakaan UIN Raden Fatah Palembang. MATICS: Jurnal Ilmu Komputer Dan Teknologi Informasi, 10(2), 52-58.

[8] Sari, N. F. A. T. (2016). Penggunaan Association Rule Mining Algoritme CT-PRO dalam Proses Penentuan Pola Tindak Kejahatan Perdagangan Manusia. Tesis Program Studi S2 Ilmu Komputer Universitas Gadjah Mada.

[9] Tan, P., Steinbach, M., \& Kumar, V. (2006). Introduction to Data Mining. AddisonWesley. 